\title{
"You Will Always Have the Poor": A Reflection on the Paradox of Justice as Law
}

\author{
Duncan French
}

Head, and Professor of Law, Lincoln Law School, Lincoln, UK dfrench@lincoln.ac.uk

\begin{abstract}
Calls for, and arguments around, fairness and justice are an essential element of international law; more so in certain areas - environment and natural resources, development - than in others, namely, the structural design of the discipline, State responsibility, formation of custom and acquisition of territory. The article thus considers the question whether there is an obligation of fair entitlement in international law, with particular reference to various matters of territory. With reflections on the discrete questions of territorial loss through sea-level rise and the role of equity in maritime delimitation, the article considers the role of fairness and justice in international law. The article concludes nevertheless that though fairness is an important and emotive value to strive for within legal and political discourse, it can become a dangerous entitlement when it trumps or usurps established rules of international law.
\end{abstract}

\section{Keywords}

fairness - justice - territorial disputes - sea-level rise - maritime delimitation

\section{Introduction}

In one of the most curious passages in the Bible, Jesus says "you will always have the poor". In more modern parlance, this might be taken to mean the

1 John 12:8 (New International Version). 
minority, the disadvantaged, the dispossessed, the marginalised, or even just the merely aggrieved. The point being made is that however worthy one's efforts, there will always be inequality; that it is not possible - or more controversially, always desirable - to seek to correct all wrongs. The purpose of this article is to consider this idea within the context of international law; and in particular whether there is an obligation of fair entitlement in international law. In other words, because something is perceived as being unfair, must it invariably be put right?

Of course, ideas of fairness and justice are generic, in that they pervade every area of human relations, and to the extent that the one impinges upon the other: international law. ${ }^{2}$ The debates are often most visible in matters that relate to, or impact upon, North-South relations, ${ }^{3}$ and in particular the allocation of resources, be they financial or natural resources. ${ }^{4}$ However, whereas achieving justice as a goal of multilateral negotiations on such matters as trade, investment and environment seems a wholly positive - if not an inevitable outcome States should strive to achieve; as regards those rules which are foundational to the structure of international law, such as the formation of custom, State responsibility, and the acquisition of, or shifting title to, territory, trying to attain justice and embed fairness can actually be perceived as contrary to the attainment of legal certainty, if they are viewed as being relevant at all. ${ }^{5}$ Thus, though the former issues are susceptible to genuine international debate around what justice might mean in a particular context, the extent to which justice is relevant - never mind can be achieved - on the latter issues is much more contested. These are matters, rightly or wrongly, where if justice and fairness exist, they are often perceived as a characteristic inherent to - rather than an overt objective of - the formalities of the legal order.

These are, of course, broad themes. For the purposes of this article, I will seek to relate them to the particular title of this issue: "self-determination, resources and borders". As a matter of selection, this article will proceed, once it has considered the topic in general terms, to reflect on two distinct examples; first, territorial loss through climate-change induced sea-level rise and

2 See T. Franck, Fairness in International Law and Institutions (Oxford University Press, Oxford, 1995).

3 See L. Boisson de Chazournes and V. Gowlland-Debbas (eds.), The International Legal System in Quest of Equity and Universality (Brill, Leiden, 2001).

4 See N. Schrijver, Sovereignty over Natural Resources: Balancing Rights and Duties (Cambridge University Press, Cambridge, 1997).

5 It is interesting to note that Franck in his wide-ranging work spends very little time on these structural aspects of international law. 
secondly, the controversial 2014 judgment of the International Court in Peru v. Chile on maritime delimitation. Both raise specific (and very different) issues, though each case study in its own way reflects the tension as to how far international law can - and should - respond to claims of 'entitlement' in the face of inequity, either actual or perceived. In both cases, the argument relates, in part, to correcting historical wrongs but also, in part, to achieving what is considered to be a fairer future (premised on some form of distributive justice).

There are, of course, many other possible - perhaps even more obvious examples within the scope of the special issue; the principle of self-determination itself and the existence of the corollary right to remedial secession are particularly glaring and controversial instances. In either case, how far does such a principle/right not only encapsulate varying notion of justices, but also how far might they justify an alteration to the traditional legal structuring of States? However, other articles in this special issue touch upon remedial secession, ${ }^{6}$ and I leave it to the reader themselves to consider the validity of that particular intractable issue through the lens of justice and fairness. This is not (just) a caveat for a lack of space in my own article. Ideas of justice and fairness are invariably and ultimately subjective, and on any topic views as to what they demand and whether they are, or can be, achieved are open to shifting - critics might say indeterminate - interpretations.

Nevertheless, as regards the two instances chosen, there are some very clear fairness-cum-justice questions ${ }^{7}$; though identifying them is one thing, seeking their resolution is quite another. The article will conclude by suggesting that international law is often negotiated - and disputes argued - on the basis that the outcome should be 'fair' at some meta-level (and to that extent, both as a moral principle and political ideal, the law should always try to reflect a general sense of justice). What is much more problematic is to demarcate where this should end so as to prevent fairness-cum-justice becoming a perpetual legal entitlement; where responding to any sense of inequality or injustice is so elevated above other norms that the law itself becomes dangerously uncertain.

6 See S.F. van den Driest, 'From Kosovo to Crimea and Beyond: On Territorial Integrity, Unilateral Secession and Legal Neutrality in International Law', 22 International Journal of Minority and Group Rights (2015), this issue.

7 The literature on justice and fairness - and the inter-relationship between them - is, of course, extensive and diverse. But as to how one should approach the process-driven imperative of fairness with the outcome-focus of justice, see Franck, supra note 2, pp. 22-24, in particular p. 23: "[a] fairness claim advanced from the perspective of legitimacy may clash with a fairness claim based on distributive justice. The two are independent variables in the concept of fairness". 
Removing injustice and improving fairness are, of course, worthy to strive for who would deny them? - however embedding them in law as constant demands is an altogether different (and a much more legally questionable) endeavour. This is not to defer to the status quo- that things must never change (climate change, for one is invariably a case in point) - but it is merely to beg the question as to the perceived value of requiring, through law, untrammelled fairness over all else in all situations.

2

\section{Fairness and Justice in Territorial and Resource Disputes: An Initial Reflection}

In disputes concerning territory and territory-related resource claims, there is a particular tension between the application of legal rules, on the one hand, and a tendency - usually within the broader context of legal argumentation and the wider political constituencies in which the law often plays out - to resort to underlying justifications of justice and fairness, on the other. Whether it is determining who has title to territory, or ascertaining resource distribution -

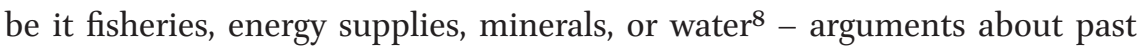
wrongs and future entitlement are usually not far from the surface. This focus on justice - qua - outcomes invariably diminishes - though does not subjugate altogether - the contrasting argument that the legitimacy (including the transparency) of, and certainty within, a legal rule is itself a manifestation of fairness between participants. ${ }^{9}$

But if fairness and justice provide a "background language" to almost any legal claim - in almost any area of legal dispute - there is something particularly problematic in its use within the stricter confines of territorial disputes. Despite the well-repeated adage: " $\mathrm{i}] \mathrm{t}$ is for the people to determine the destiny of the territory and not the territory the destiny of the people", ${ }^{10}$ when one

8 More recently, this has been supplemented by a view that such allocation must also be sustainable, see N. Schrijver, The Evolution of Sustainable Development in International Law: Inception, Meaning and Status (Martinus Nijhoff, Leiden, 2008) pp. 173-175.

9 Cf. C. Okereke, Global Justice and Neoliberal Environmental Governance: Ethics, Sustainable Development and International Co-operation (Routledge, London, 2010) p. 35: "the stuff of any theory of justice resides in the principle of distribution it recommends, and questions about procedure are relevant only as a means to establish the morality of the outcome or combination of outcomes envisaged".

10 Judge Dillard, Separate Opinion, Western Sahara, 16 October 1975, ICJ, Advisory Opinion, I.C.J. Reports 1975, p. 122. 
reviews the formalism of legal arguments in territorial disputes, especially before the International Court, there often appears a distinct disjunction between legal rules and broader claims for (outcome-orientated) justice.

For instance, when one considers the application and requirements of effectivités in the determination of territorial disputes, there can often appear to be a rather clinical approach to delimitation and title. As Crawford recently asked rhetorically (and then provides the answer): "[i]s there a rule of law inhibiting the transfer of territory if certain minimum conditions of local consent are not fulfilled? ... there is insufficient practice to warrant the view that a transfer is invalid simply because there is no sufficient provision for expression of opinions by the inhabitants".11 Any broader sense of injustice felt by the communities most directly affected by the abstract application of international law in these instances is rarely captured by legalistic doctrines, and human rights discourse does not seem to penetrate title, and certainly not delimitation, decisions. ${ }^{12}$

Of course, there are even clearer - paradigmatic - instances in the international legal order, revealing very acutely the tension between 'law' and 'fairness'. One particularly good example is the normative clash between the principle of self-determination of peoples and the application of the boundary principle of uti possidetis; which is often perceived as the ultimate preference for stability over rights. ${ }^{13}$ Nevertheless, beyond this, international law contains within itself a more general tension as to the scope and reach of justice and its direct application through law. This is often particularly noticeable when disputes are taken to third party resolution, which highlights often acutely the normative gap between the claimed value of justice in international relations in contrast to the formal need for legal stability and certainty. Recourse to justice and fairness places international courts and tribunals in an unenviable position; as such concepts are neither objectively understood nor will be uniformly interpreted in the same manner by the parties or the bench. ${ }^{14}$ One need

11 See e.g., J. Crawford, Brownlie's Principles of Public International Law (Oxford University Press, Oxford, 2012) p. 243.

12 As an example of limited interest in human welfare in such cases, see Cameroon v. Nigeria, 10 October 2002, ICJ, Judgment, I.C.J. Reports 2002, p. 452: "The Court further notes that the implementation of the present Judgment will afford the Parties a beneficial opportunity to co-operate in the interests of the population concerned, in order notably to enable it to continue to have access to educational and health services comparable to those it currently enjoys".

13 Franck, supra note 2, p. 148.

14 In this context, see also the valid point that "litigation is a good way of disposing of a troublesome issue when the resolution of a dispute is considered to be more important 
only consider the evolving jurisprudence, and concurrent critique (judicial and otherwise), on maritime delimitation over the last forty-five years since North Sea Continental Shelf Cases (1969) ${ }^{15}$ - as the International Court sought to first embrace and then move away from overt reliance on equitable principles in the determination of maritime boundaries ${ }^{16}$ - to reflect on the contested nature of fairness within international legal discourse. As Judge Gros memorably said, it is "an equity beyond the law, detached from any established rules, based solely on whatever each group of judges seised of a case declares itself able and free to appreciate in accordance with its political or economic view of the moment". ${ }^{17}$

But this merely begs the question: how is fairness achieved in a global context? Claims for fair allocation are premised on so many opposing factors of historical entitlement, present-day need and future want that one must question the ability or capacity of the international system to achieve justice. As Lowe once remarked, "how can the equities of multilateral, global problems be established? They can be negotiated, with the result that no state may be in a position to deny that the negotiated solution is equitable". ${ }^{18}$ Realistically, is that as good as we should expect to achieve? Before moving on to the case studies, it is therefore worthwhile considering the wider claims to fairness and justice in international law. ${ }^{19}$

It is a matter of contention whether international law has, as one of its objectives, the promotion of fairness and the achievement of justice, at least beyond

than the result". J. Merrills, International Dispute Settlement (Cambridge University Press, Cambridge, 2011) p. 291.

15 North Sea Continental Shelf (Federal Republic of Germany/Netherlands) / North Sea Continental Shelf (Federal Republic of Germany/Denmark), 20 February 1969, ICJ, Judgment, I.C.J. Reports 1969.

16 Crawford, supra note 11, p. 288: "the 'principles' are general in character...the term 'equitable'...sets an amorphous standard".

17 Judge Gros, Dissenting Opinion, Delimitation of the Maritime Boundary in the Gulf of Maine Area (Canada/United States of America), 12 October 1984, ICJ, Judgment, I.c.J. Reports 1984,p. 388.

18 V. Lowe, 'Sustainable Development and Unsustainable Arguments' in A. Boyle and D. Freestone (eds.), International Law and Sustainable Development: Past Achievements and Future Challenges (Oxford University Press, Oxford, 1999) p. 29.

19 This section builds upon some earlier thoughts: D. French, 'Global Justice and the (Ir)relevance of Indeterminacy', 8 Chinese Journal of International Law (2009) p. 593. 
the rhetorical or meta-level of narrative. Franck argues, perhaps unsurprisingly in his work Fairness in International Law and Institutions, that assessing fairness is indeed a valid consideration within international legal norms:

Like any maturing legal system, international law has entered its postontological era... emancipated from the constraints of a defensive ontology, international lawyers are now free to undertake a critical assessment of its content... And, the most important question: Is international law fair? ${ }^{20}$

Whether fairness is an explicit or a defined objective of the international legal system, or is merely instrumental to, or a corollary of, law's normal operation, is however not always clear. And there is a real risk that one can see fairness (or unfairness) in every legal rule and process. Certainly, if one looks hard enough, one can find the reverse - inequity - everywhere. Equally there is a danger of pointing out minor unfairness whilst missing macro-injustice.

Of course, in any philosophical discussion of justice, one often begins by turning to the liberal theory of John Rawls, especially as its focus on moderate scarcity and the acceptance of a difference principle to maximise the benefits for the least fortunate would suggest itself as extremely relevant to the current global order. As has been noted, "the difference principle contains some really explosive material, precisely with regard to resource justice". ${ }^{21}$ Rawls himself discounted the possibility of a global understanding in his 1999 work, The Law of Peoples. For Rawls, between peoples - in contrast to persons within the internal framework of a State - there is no duty of justice.

While there are indeed other obligations governing the relations between them, securing justice is not one of them. As Chartier notes in discussing global justice, "[a] Rawlsian Law of Peoples entails neither the equalisation of the conditions of those who belong to different peoples nor the globalisation of Rawls's difference principle, according to which inequalities are permissible only to the extent that they benefit the worst-off". ${ }^{22}$ At most, Rawls argues there is a duty of assistance limited to enabling "burdened societies to ... become self-sufficient members of the Society of Peoples.". ${ }^{23}$ In other words, the pull of humanitarian values extends only so far as ensuring a people can

\footnotetext{
$20 \quad$ Franck, supra note 2, p. 6.

21 W. Sachs and T. Santarius, Fair Future: Resource Conflicts, Security and Global Justice (Black Point, San Francisco, 2007) p. 130.

22 G. Chartier, 'Peoples or Persons? Revising Rawls on Global Justice', 27 Boston College International and Comparative Law Review (2004) p. 79.

Ibid.
} 
themselves "overcome hardship ... and can 'manage [its] own affairs reasonably and rationally ... even though the now well-ordered society may still be relatively poor".' 24

This denial of justice at the global level, though premised largely upon the limited nature of international society vis-à-vis the concerted organisation of domestic societies, it is also partially premised upon more pragmatic uncertainties surrounding justice. A standard of conduct premised upon justice "may well lack 'a defined goal, aim, or cut-off point, beyond which aid may cease" and might thus, presumably, be both oppressively demanding and difficult to implement. ${ }^{25}$ In contrast, the more limited duty to assist "ceases when this goal is reached, it has a target". ${ }^{26}$ This need for certainty is, of course, a valid one; it builds upon my previous comment that fairness as a constant right has the potential to be anarchic and ultimately destructive.

As has already been remarked, one should also distinguish between fairness as a goal of multilateral negotiations on such matters as trade and environment, and its arguably much more constrained role in those aspects of international law, which are foundational to its structure and co-existence. In terms of the latter, the following seems particularly apt: "justice in a given society, as well as international justice if it exists, must consist purely of conventions... that will enable individuals (and nation states) to pursue and maximise their gains under the constraints of an agreed legal framework".27

It is within the space created by this relationship between "maximising gains", on the one hand, and "the constraints of an agreed legal framework", on the other, where justice if it is achievable in international law must occur. Unsurprisingly, it is those with the clearest demands for justice - the "poor" from the Bible that I have extrapolated and broadened for modern times - that are (rightly) insistent that the legal framework operates so that gains are maximised for all. Such claims are, of course, increasingly numerous; from the global South, indigenous peoples, minorities, the marginalised, and the disenfranchised - indeed, any attempt to be exhaustive would simply highlight a category that has been missed.

Moreover, justice will remain a contested proposition in international law for as long as the State is both the focus of claims for justice (for instance, as regards inequity in North-South relations) and of claims of injustice (for

\footnotetext{
24 Ibid., quoting J. Rawls, The Law of Peoples (Harvard University Press, Harvard, 1999) p. 111.

25 Ibid., pp. 78-79, quoting Rawls, p. 106.

$26 \quad$ Ibid., p. 79 .

27 Okereke, supra note 9, p. 45.
} 
instance, as regards human rights abuses committed by States). Thus, any attempt at discerning a global principle of justice, which centres upon the State as fundamental actor, might be said to be doomed to failure. ${ }^{28}$ If one considers this too negative a prognosis; consider the initial wording of the little known draft declaration on the Right of Peoples and Individuals to International Solidarity ${ }^{29}$ - noting that even the title captures one of the central dilemmas of justice within international law; whether our focus should be 'Peoples [or] Individuals'? The draft defines international solidarity as follows:

[T] he union of interests, purposes and actions between and among peoples, individuals, States and their international organizations, to preserve the order and the very survival of international society, and to achieve common goals that require international cooperation and collective action based on the international normative system of obligations, duties and responsibilities, which they implement and practice to foster peace and security, development and human rights, in accordance with the Charter of the United Nations. ${ }^{30}$

This is a broad - universalist - understanding of solidarity; ${ }^{31}$ and it is certainly wider than many would be willing to acknowledge, or to accept. Of course, as a noun-descriptor of the values that bind States and peoples together, solidarity can be reflective of either an expansive or a more exclusive commitment between them; a weak or strong style of solidarity. This may correspond with the contrast in liberal political thought between the 'international society' of States and the narrower understanding of an 'international community', which is comprised of a sub-set of paradigm Western States. ${ }^{32}$ In particular, whereas solidarity in democratic and human rights values amongst the international

28 French, supra note 19, p. 6oo: "the State continues to represent, in many instances, the least-worst model of reflecting the collective interests of politically-organized, as well as (usually) geographically situated, communities...whether States can ever truly function as the appropriate 'vessels' to capture the internal (popular) sovereignty of their communities, rather than acting merely as proxies of the same, is perhaps a different - certainly, more fundamental - question".

29 UN Doc. A/Hrc/26/34/Add.1, 1 April 2014.

$30 \quad$ Ibid., Article 1.

31 See also K. Wellens, 'Revisiting Solidarity as a (re-)Emerging Constitutional Principle: Some Further Reflections', in R. Wolfrum and C. Kojima (eds.), Solidarity: A Structural Principle of International Law (Springer, New York, 2010) p. 4.

32 R. Buchan, 'A Clash of Normativities: International Society and International Community', 10 International Community Law Review (2008) p. 3. 
community is very much intended to be a self-defining distinction vis-à-vis other States, solidarity within the international society as a global value applicable to all is based on more elementary, if less exact, notions of humanity and fairness. Thus, if justice is central to our understanding of solidarity, we will also need to determine how far - as a concept - it extends, and to whom does it apply?

Turning now to the case studies. They can only be briefed outlined, and for the most part, only need to be. More important are the aspects of fairness and justice they suggest. Considering territorial loss through climate change induced sea-level rise, for instance, highlights issues of corrective justice and solidarity. On the other hand, the recent International Court's approach to maritime delimitation in Peru v. Chile (2014) focuses more on procedural fairness and distributive justice.

The first case study is on future territorial loss through sea-level rise caused by climate change and the possible response and ultimately relocation scenarios open to affected States. As is increasingly recognised, many low-lying particularly Pacific and Indian island developing States will be some of the first to face the extreme effects of climate change; some already have. ${ }^{33}$ Though substantial or even wholesale territorial loss is likely to affect only a small group of States - Kiribati, Nauru, Vanuatu, Marshall Islands, and the Maldives - the point at which these (and other) territories will become inhabitable and inhospitable will occur significantly before this date. ${ }^{34}$ Loss of fresh water, irreversible impacts on agriculture, food production, ecosystem renewal, tourism and employment as well as voluntary and involuntary migration will all negatively affect the political, economic and social sustainability of these States. ${ }^{35}$ As

33 IPCC Summary for Policy-Makers of Synthesis of Fifth Assessment Report <www.ipcc .ch/>, visited on 10 April 2015: "Coastal systems and low-lying areas are at risk from sea-level rise, which will continue for centuries even if the global mean temperature is stabilised".

34 Of course, sea-level rise is not just an issue for low-lying island States, but coastal communities generally, especially in the global South.

35 Intergovernmental Panel on Climate Change Summary for Policy-Makers of Working Group II Report (Impacts, Adaptation and Vulnerability) Report <www.ipcc.ch/>, visited on 10 April 2015: "Risk of death, injury, ill-health, or disrupted livelihoods in low-lying coastal zones and small island developing states and other small islands, due to storm surges, coastal flooding, and sea level rise". 
must be obvious, this is a human rights, humanitarian and developmental issue as much as it is an environmental one.

Much international legal scholarship is focusing on what loss of territory as a constituent requirement under the Montevideo criteria for Statehood might mean for the continuation of these countries, as well as a range of innovative proposals as to how such States might continue to survive post territory-loss. They range from the technological ("floating islands") ${ }^{36}$ through to the more practical - if politically difficult. To quote a paper by Rosemary Rayfeuse and Emily Crawford: "[t]raditional responses to the resolution of the statehood dilemma include the acquisition of new sovereign territory from a distant state by treaty of cession or merger with another state by way of some form of federation". ${ }^{37}$ Many other legal imponderables of course exist, including the so-called "baseline dilemma" (should baselines shift with rising tides?) and the related issue as to what to do about maritime entitlements ${ }^{38}$ and whether refugee status should adapt to include people displaced by climate change. ${ }^{39}$

My purpose is not to go into this discussion, but rather to pose a singular question - relating it to the wider theme of stability and fairness - how does one frame such a debate? In circumstances such as these, traditional law seems at best problematic and, at worse, obstructive. The law rarely has pragmatic or politically acceptable solutions for situations such as these. Equally, we are loath to acknowledge normative lacunae. In the discussion on climate change and the potential loss of statehood, there can be a divide between law and justice. Whereas some arguments seek to take the present law and via a series of normative contortions apply it to the present problem (e.g., how can the Montevideo criteria on statehood still be met if there is no territory?), there is a risk that they ignore the wider political and ethical imperatives of a community

${ }_{3} 6$ See J. Fehrenbacher, 'Maldives To Fight Rising Sea Levels With Floating Islands', Inhabit, 3 May 2010, <inhabitat.com/maldives-to-fight-rising-sea-levels-with-floating-islands/>, visited on 24 November 2014.

37 E. Crawford and R. Rayfuse, 'Climate Change and Statehood' in R. Rayfuse and Shirley V. Scott (eds.), International Law in the Era of Climate Change (Edward Elgar, Cheltenham, 2012) p. 249. See also D. Freestone, 'International Law and Sea-Level Rise', in R. Churchill and D. Freestone (eds.), International Law and Global Climate Change (Kluwer Law International, The Netherlands, 1992) p. 109, and more recently M. Gerrard and G. Wannier (eds.), Threatened Island Nations: Legal Implications of Rising Seas and a Changing Climate (Cambridge University Press, Cambridge, 2013).

38 Rayfuse and Scott, supra note 37, ch. 6.

39 Ibid., ch. 3. 
response. ${ }^{40}$ On the other hand, those arguments, which demand a moral response, often fail to engage with the legal minutiae of their suggestions. ${ }^{41}$

So to return to my question - is the loss of territory due to sea level rise a matter that should demand a global response? Almost certainly yes. But on what basis is such a response premised? Humanitarian? Moral? Because of the legal culpability of those States that have historically polluted the most, or those that now are? Ultimately, how might the international community respond to a complex and multilateral injustice in such a way that it doesn't become 'oppressively demanding and difficult to implement'?

Alternatively phrased, before one can even enter the debate, one needs to be able to reasonably ascertain its parameters. What rules and principles might guide the international community in giving redress to this very extreme form of injustice? Even where the call for justice is so apparent - as it is here - and the argument is validly made that the law must respond, this rarely answers the question as to what the law must do, and what it might entail, in any particular situation. Justice may be the objective which the international community is morally required to achieve in this case - and solidarity might even be accepted as the value which will guide such action ${ }^{42}$ - but neither provides anything like the necessary detail nor can they replace the need for reasonably precise and enforceable legal rules. Only broad-based negotiation, of all interested parties, coming to the negotiating table with bona fides commitment, can achieve that. Law as an outcome of such negotiation may fortuitously reflect a generalised sense of justice, but it is rarely capable of being pre-determined in abstracto. Climate justice has become a popular phrase, ${ }^{43}$ and it points us in the right direction, but it lacks normative content.

40 One might ask how far discussion of the Sovereign Order of Malta (see Crawford and Rayfuse, supra note 37, pp. 251-252) where "sovereignty and nation can be separated from territory", rather than being a helpful historical analogy merely exacerbates the sense that the international community lacks the principled tools necessary to tackle something as challenging as climate change.

41 The suggestion for the re-allocation of land from one sovereign to another would aptly seem to fall into this category. The language is often justice-imbued but rarely normative: $<$ www.smh.com.au/environment/climate-change/climate-change-castaways-consider -move-to-australia-20120106-1pobf.html>, visited on 24 November 2014.

See also draft Declaration on Right of Peoples and Individuals to International Solidarity (supra note 29), where at draft Article 9: "[t]he right to international solidarity entails a human rights based approach to international cooperation and all global partnerships in responding to global challenges such as those relating to... climate change".

See 'Climate Justice and International Environmental Law: Rethinking the North-South Divide', 10:2 Melbourne Journal of International Law (2009). 
The second case study is at a much different scale, namely the International Court's 2014 Judgment in Peru v. Chile on the delimitation of a single maritime boundary. ${ }^{44}$ This was a particularly contentious delimitation dispute arising from a far from easy historical relationship between these two States. The arguments of the parties though heavily legalistic - as to be expected before the Court - also highlighted the political and sovereign components of the nature of the dispute. The challenge for the Court, as in all delimitation cases, is to ensure adherence to the relevant law whilst concurrently being seen to consider the arguments and the particular circumstances submitted by each party. As is wellknown, the Court's jurisprudence on maritime delimitation has proven to be a story of judicial uncertainty - if not academic woe - for many decades, though many felt the 2009 judgment in Romania v. Ukraine was meant to bring a certain level of consistency back to the Court's approach. ${ }^{45}$ Of particular importance was the Court's reaffirmation of the principle that "the sharing out of the area is ... the consequence of the delimitation, not vice versa" (Jan Mayen (1993). ${ }^{46}$

The principal issue before the Court is relatively easy to paraphrase; it was whether a prior - if implicit - maritime boundary existed between the Parties at the lateral point where the land boundary met the sea (as Chile argued) or whether it was for the Court to delimit de novo (as Peru argued). There was a particular tension around the so-called "triangle" claimed by Peru, but considered high seas by Chile. ${ }^{47}$ Much of the written submissions were devoted to this question by both parties. The Court came to the view that an agreed lateral maritime boundary did indeed exist; but only up to eighty nautical miles from the coastline. As the Court found:

On the basis of the fishing activities of the Parties at that time, which were conducted up to a distance of some 60 nautical miles from the main ports in the area, the relevant practice of other States and the work of the International Law Commission on the Law of the Sea, the Court considers that the evidence at its disposal does not allow it to conclude that the

\footnotetext{
44 Peru v. Chile, 27 January 2014, ICJ, Judgment, I.C.J. Reports 2014.

45 Romania v. Ukraine, 3 February 2009, ICJ, Judgment, I.C.J. Reports 2009.

46 Peru v. Chile, supra note 44, para.11, restating Maritime Delimitation in the Area between Greenland and Jan Mayen (Denmark v. Norway), ICJ, Judgment, I.C.J. Reports 1993, p. 67, para. 64 .

47 <pilr.blogs.law.pace.edu/2014/o1/18/peru-v-chile-maritime-dispute/>, visited on 23 November 2014 .
} 
agreed maritime boundary along the parallel extended beyond 80 nautical miles from its starting-point. ${ }^{48}$

The arbitrariness of eighty nautical miles - a figure unknown in the international law of the sea and apparently to the parties themselves - is not lost on some of the judges, both those dissenting and even those like Judge Owada who concurs with the final decision..$^{49}$ As President Tomka perhaps succinctly frames it:

The fundamental issue is whether an agreement concluded for...a zone of tolerance for small fishing vessels with insufficient navigation equipment, could have implicitly determined the outer limit of the pre-existing maritime boundary at a distance of 80 nautical miles when the Parties openly and publicly claimed maritime zones extending at least to 200 nautical miles. Such an interpretation seems to run counter to the intention of the Parties when the evidence is appreciated as a whole. ${ }^{50}$

The joint dissent of four judges is plainer: "the majority labours to argue in favour of the idea that the agreement between Peru and Chile covers a distance of 80 nautical miles from the continental coast". 51

This curious decision is almost wholly inexplicable without recourse to maritime maps. ${ }^{52}$ And it may be wondered how this relates to the wider themes of fairness and justice identified in this article. But what becomes apparent when one does review the delimitation is that whereas the Peruvian and Chilean claims were significantly divergent, with each giving to itself a noticeable benefit, the delimitation affected by the Court's recognition of an 80 nautical mile lateral boundary then followed by an equidistance line has an altogether different outcome, almost a mid-way point between the two positions claimed. Is this a valid approach - Solomon-like in its judgment - or an attempt to achieve equity, which is disconnected from the law? To repeat the quote from Jan Mayen: "the sharing out of the area is ... the consequence of the

48 Peru v. Chile, supra note 44, para. 117.

49 Judge Owada, Separate Opinion, Peru v. Chile, supra note 44, paras. 25 and 28.

$50 \quad$ President Tomka, Declaration, Peru v. Chile, supra note 44, para. 4.

$5^{1}$ Judges Xue, Gaja, Bhandari and Judge Ad Hoc Orrego Vicuña, Joint Dissenting Opinion, Peru v. Chile, supra note 44, para. 2.

$5^{2}$ For an unofficial but informative pair of maps, see <www.unfalumni.org/the-international-court-of-justice-in-the-hague-splits-disputed-waters-in-chile-peru-dispute/>, visited on 23 November 2014. 
delimitation, not vice versa". The International Court has always shied away from distributive justice - recognising that it strains both the foresight (and legitimacy) of the Court and the goodwill of the parties - nevertheless, in this instance, it seems to have come close to doing just that.

My principal concern with the judgment in Peru v. Chile is not necessarily that the end-result is manifestly wrong, or even that the law is misunderstood or misinterpreted, though some of the dissenting judges have certainly indicated that there is a significant problem in this regard. Rather, the concern is that achieving a fair outcome was seemingly - and most explicitly - guiding the reasoning of how the Court came to its judgment. Of course, this happens more than we would like to admit, but in this case it seems especially overt. But in looking at this case, in the search for doing justice to both sides, the Court arguably stretches its judicial role to achieve peaceful settlement, and is at the expense of both legal reasoning and the general standing of the Court?

In this short summary of the case $\mathrm{s}^{53}$ - with admittedly little reference to the complexity of the argument around the underlying State practice and treaty provisions - it is perhaps too brief to come to any firm conclusions. Nevertheless, has international law been well served by this judgment? Certainly, it seems curious. A delimitation argued by neither - premised on a nautical limit not known in the law of the sea - but which has the effect of giving to each a more equitable share that what they were prepared to admit to the other. If justice is the purpose of the International Court - and some might argue that is its overriding aim - then perhaps, yes, it is a positive result. ${ }^{54}$ But if the International Court as a legal tribunal must above all things apply the law, then reading between the lines of the diplomatic language used in the dissenting views of some of its own judges, this was at best a questionable decision, weakly reasoned.

And if ongoing respect for the law is one of the major functions of dispute settlement, will this give confidence to either other States in future maritime delimitation cases or, more specifically, the parties directly involved? The ongoing case of Bolivia v. Chile, which raises even more sensitive issues for

53 For a fuller discussion see X. Fuentes Torrijo, Comentario a la Sentencia de la Corte Internacional de Justiciaen el casoPerü contra Chile (on file with the author).

54 D. Anton, The Maritime Dispute between Peru and Chile <www.e-ir.info/2014/03/18/themaritime-dispute-between-peru-and-chile/>, visited on 24 November 2014: "The peaceful resolution of this maritime boundary dispute is to be welcomed, especially given that its origins began through hostilities and the use of force. It seems plain that the Court achieved (even if it was not striving for) a reasonable compromise between the absolutist positions that had been staked out by Peru and Chile". 
Chile - namely an obligation to negotiate access over its land territory - now takes place against the backdrop of what might appear to be judicial activism that any State would find troubling, but especially so for one of the same parties. Striving to achieve justice between the parties is one thing; failure to provide convincing reasoning for doing so might itself constitute a breach of procedural fairness, if nothing else.

The purpose of this article has not been to dismiss fairness and justice as values in international law; indeed, as someone who works primarily on international environmental and developmental law, they are staple ingredients in many of my writings. ${ }^{55}$ And as these case studies reveal, the rhetoric of fairness and justice are powerfully emotive ideas in a wide range of situations. Indeed, without a continuous call for fairness and justice, the international system is in danger of stagnating at the expense particularly of the global poor (however defined). To argue otherwise would perpetuate uneven and often inequitable power relationships. As Chimni notes: "[ $t]$ he formal conception of the international rule of law is minimalist in its orientation as it tends to privilege the value of order over that of justice. However, there have emerged, or are in the process of emerging, international institutions that seek to expand the scope of international law".56

So why my reticence? Why suggest in this article that these values must invariably have outer limits when operating within the confines of international law. As I said at the beginning, what concerns me is not the achievement of justice and fairness through the application of law but rather the risk that they become elevated above legal norms, so that the law itself becomes dangerously uncertain and legal stability is thereby threatened. This is not to deny the importance of values; but to question what they entail in any particular circumstance. In short, there will always (have to) be necessary constraints as to how far law can go to meet justice.

55 D. French, 'Developing States and International Environmental Law: The Importance of Differentiated Responsibilities', 49 International and Comparative Law Quarterly (2000) p. 35 .

56 B.S. Chimni, 'Legitimating the International Rule of Law', in J. Crawford and M. Koskenniemi (eds.), The Cambridge Companion to International Law (Cambridge University Press, Cambridge, 2012) p. 293. 
But not accepting a negative is not always the same as immediately demanding a positive. If fairness-cum-justice were to be seen as an instantaneous and perpetual legal entitlement, challenging almost any tenet of the international legal system, what would result would be little more than a selective pick-andmix of legal argumentation. Justice should be the goal, but rarely should it be the rule.

So to conclude, as international lawyers we should acknowledge valid calls for justice within law - at the same time recognising (if not accepting) the inevitability of its unfair application at some point and in some situations. Both case studies in their own way revealed the significance, yet also limitations, of always seeking to achieve a just outcome; we would thus do well to remember that the role of law is not invariably to perfect inequality, and it is sometimes a risky venture if we try. In particular, let me be clear; I am not at all suggesting we should not respond to the plight of those in distress, such as climate refugees - it is undoubtedly becoming a humanitarian crisis requiring a global response - but I would caution against the idea that inequality can only be tackled through the dismantling of established legal principles. 